\section{Shoot and Root Responses of Eight Subtropical Species Grown in Cupric Hydroxide-treated Containers}

\author{
Sven E. Svenson, Diane L. Johnston, and Bonnie L. Coy \\ Fort Lauderdale Research and Education Center, University of Florida, 3205 \\ College Avenue, Fort Lauderdale, FL 33314 \\ Additional index words. Cedrela odorata, Eriobotrya japonica, Leea coccinea, Peperomia \\ serpens, Peperomia obtusifolia, Radermachera sinica, Schefflera actinophylla, Swietenia \\ mahagoni, root malformation
}

\begin{abstract}
The effect of $\mathrm{Cu}(\mathrm{OH})_{2}$ applied to interior container surfaces on shoot and root responses was evaluated on eight species cultivated in subtropical regions. Species studied were Cedrela odorata L.; Eriobotrya japonica (Thunb.) Lindl.; Leea coccinea Planch.; Peperomia serpens (Swartz.) Loud.; Peperomia obtusifolia (L.) A. Dietr.; Radermachera sinica (Hance) Hensl.; Schefflera actinophylla (Endl.) Harms; and Swietenia mahagoni (L.) Jacq. No foliar Cu toxicity symptoms developed on any species during the study. Swietenia mahagoni seedlings grew faster in height and had larger shoot : root ratios when grown in $\mathrm{Cu}(\mathrm{OH})_{2}$-treated containers than in nontreated containers. Leea coccinea seedlings were taller and produced more shoot dry weight when grown in $\mathrm{Cu}(\mathrm{OH})_{2}$-treated than in control containers. Applying $\mathrm{Cu}(\mathrm{OH})_{2}$ did not influence shoot growth of the other six species studied. Root coverage reduction on the exterior of the rootball in $\mathrm{Cu}(\mathrm{OH})_{2}$-treated containers was excellent for all species studied, and coverage was completely eliminated in three species. Shoot and root responses to $\mathrm{Cu}(\mathrm{OH})_{2}$-treated containers varied among subtropical species, which is consistent with shoot and root responses among temperate species.
\end{abstract}

Plants with vigorous root growth produce circling, malformed root systems when grown in containers. To correct root malformation of container-grown plants, root pruning often is required at transplanting (Harris, 1992). Copper-treated containers reduced or eliminated root malformation (Arnold, 1992; Arnold and Struve, 1993; Beeson and Newton, 1992; Ruter, 1994) and increased transplant survival and regrowth in various temperate species (Struve, 1993). The influence of $\mathrm{Cu}$-treated pots on the growth of species cultivated in subtropical regions has received less study (Beeson and Newton, 1992; Svenson and Broschat, 1995; Svenson and Johnston, 1992). Our objective was to evaluate the effects of $\mathrm{Cu}(\mathrm{OH})_{2}$-treated containers on shoot and root responses of eight species commonly cultivated in subtropical regions.

\section{Materials and Methods}

On 5 July 1991, Swietenia mahagoni (West Indian mahogany) seeds were sown two per pot, in 50 round pots (top $=90 \mathrm{~mm}$ in diameter)

Received for publication 21 Sept. 1994. Accepted for publication 4 Nov. 1994. Florida Agriculture Expt. Station Journal Series no. R-03931. Donation of Spin Out and financial assistance from Griffin Corp. is gratefully acknowledged; donation of Cedrela seed by F.W. Howard is gratefully acknowledged. The cost of publishing this paper was defrayed in part by the payment of page charges. Under postal regulations, this paper therefore must be hereby marked advertisement solely to indicate this fact. filled with 0.4 liters of ProMix BX medium (Premier Brands, Stamford, Conn.). Seedlings were thinned to one per pot at emergence. On 9 Aug. 1992, 40 seedlings of similar height and stem diameter were selected. Ten seedlings were separated into shoots and roots and dried ( 3 days at 70C), and 30 were potted into round containers (top $=150 \mathrm{~mm}$ in diameter) filled with 2.3 liters of a 5 pine bark : 4 peatmoss : 1 sand (by volume) medium. Before being filled with medium, interior surfaces of 15 containers were painted with a liquid latex$\mathrm{Cu}(\mathrm{OH})_{2}$ compound $\left[100 \mathrm{~g} \mathrm{Cu}(\mathrm{OH})_{2} /\right.$ liter; $\approx 4.6 \%$ metallic $\mathrm{Cu}$ equivalent)], formulated as Spin Out (Griffin Corp., Valdosta, Ga.), or were left nontreated. Seedlings received a dibble application of $24 \mathrm{~g}$ Osmocote $18 \mathrm{~N}-$ 3.1P-10K, (Grace-Sierra, Milpitas, Cal.; 8- to 9-month formula) at potting. Seedlings were grown under full sun $\left[1950 \mu \mathrm{mol} \cdot \mathrm{m}^{-2} \cdot \mathrm{s}^{-1}\right.$ maximum photosynthetic photon flux (PPF) as measured with a line quantum sensor (model LI-191SA; LI-COR, Lincoln, Neb.], with natural photoperiods (lat. $26.1 \mathrm{~N}$, long. $80.2 \mathrm{~W}$; Fort Lauderdale, Fla.), $65 \%$ to $85 \%$ average relative humidity, and an average $33 \mathrm{C}$ maximum/25C minimum. Seedlings received daily irrigation supplemented with natural rainfall. A completely randomized design was used $(\mathrm{n}=15)$.

Shoot heights were measured 9 and 15 weeks after potting. Fifteen weeks after potting, shoots from treated and nontreated containers were removed from root systems and dried ( 3 days at 70C). Root coverage on the exterior of the rootball was rated using the following scale: $1,<20 \%$ of the rootball cov- ered with white root tips, no root circling; 3 , $\approx 50 \%$ of the rootball covered with white root tips, moderate root circling; and 5,> $80 \%$ of the rootball covered with white root tips, extensive root circling (Ruter, 1994). After rating the root system, roots were washed free of medium and dried. Using height measurements and dry weights, height growth rate (millimeters per day), plant growth rate (grams per day), and shoot : root ratios (grams per grams) were calculated. Data were analyzed using analysis of variance with mean separations by least squares means (SAS Institute, 1989).

On 20 Nov. 1991, seeds of Cedrela odorata (West Indian cedar) were sown as described for S. mahagoni. On 20 Feb. 1992, twentyeight seedlings of similar height and stem diameter were potted into round containers (top $=220 \mathrm{~mm}$ in diameter) filled with 5.5 liters of medium as previously described. Before being filled with medium, interior surfaces of 14 containers were treated with $\mathrm{Cu}(\mathrm{OH})_{2}$, and 14 were left nontreated. After potting, containers were topdressed with $48 \mathrm{~g}$ of Osmocote $18 \mathrm{~N}-3.1 \mathrm{P}-10 \mathrm{~K}$. Throughout the experiment, seedlings were grown in a singlelayer polycarbonate greenhouse that was shaded (Kool Ray Liquid Shade; Continental Products, Euclid, Ohio) to provide 750 $\mu \mathrm{mol} \cdot \mathrm{m}^{-2} \cdot \mathrm{s}^{-1}$ maximum PPF with natural photoperiods, $60 \%$ to $85 \%$ relative humidity, and an average $31 \mathrm{C}$ maximum/22C minimum. Seedlings were irrigated as needed. A completely randomized design was used $(n=14)$. Shoot heights were measured 8,12 , and 16 weeks after potting. Sixteen weeks after potting, shoots from treated and nontreated containers were removed from the root system and dried ( 3 days at 70C). Root coverage at the container-medium interface was rated, and data were analyzed as previously described.

Rooted cuttings of Schefflera actinophylla 'Amate' (Amate umbrella tree) were potted on 10 Dec. 1991. Experimental procedures were the same as described for $C$. odorata with the following differences: plants were potted three per container, topdressed with $70 \mathrm{~g}$ of Osmocote $18 \mathrm{~N}-3.1 \mathrm{P}-10 \mathrm{~K}$ every 5 months, grown in a screenhouse covered with black shadecloth providing $780 \mu \mathrm{mol} \cdot \mathrm{m}^{-2} \cdot \mathrm{s}^{-1}$ maximum PPF with natural photoperiods, averaged $32 \mathrm{C}$ maximum $/ 23 \mathrm{C}$ minimum, and were irrigated daily for $1 \mathrm{~h}$ using drip emitters (3.8 liters $\cdot h^{-1}$ ) following days when natural rainfall was $<25 \mathrm{~mm}$. Shoot heights were measured 12,16 , and 22 weeks after potting. Twentytwo weeks after potting, shoots and root systems were evaluated as described for $C$. odorata $(\mathrm{n}=10)$.

Uniformly graded seedling liners (20 seedlings per cell) of Radermachera sinica (China doll) were potted on 4 Feb. 1992. Experimental procedures were the same as described for S. actinophylla with the following differences: liners were potted in round pots (pots $=150$ $\mathrm{mm}$ in diameter) filled with 1.2 liters of medium, pots were topdressed with $18 \mathrm{~g}$ Osmocote $18 \mathrm{~N}-3.1 \mathrm{P}-10 \mathrm{~K}$, and plants were irrigated by rainfall supplemented with overhead irriga- 
tion (as needed). Shoot heights were measured 8 and 12 weeks after potting. Twelve weeks after potting, shoots and root systems were evaluated as described for $C$. odorata $(\mathrm{n}=10)$.

Seeds of Eriobotryajaponica (loquat) were sown on 4 Feb. 1992 as described for mahogany. Experimental procedures were the same as described for $C$. odorata with the following differences: uniform seedlings were potted in round containers (top $=150 \mathrm{~mm}$ in diameter) filled with 2.25 liters of medium, as previously described, on 19 Apr. 1992 with $33 \mathrm{C}$ maximum $/ 26 \mathrm{C}$ minimum, and shoots and root systems were evaluated 26 weeks after potting $(\mathrm{n}=14)$.

Twenty-eight uniformly graded $(300 \mathrm{~mm}$ stem length), bareroot Leea coccinea (West Indian holly) seedlings were potted on 5 Nov. 1993. Experimental procedures were the same as described for C. odorata with the following differences: containers were topdressed with $48 \mathrm{~g}$ SierraBlen $18 \mathrm{~N}-3.1 \mathrm{P}-8.3 \mathrm{~K}-1 \mathrm{Fe}$ (8- to 9 month formula; Grace-Sierra), and shoot heights were recorded 14 and 18 weeks after potting. Eighteen weeks after potting, shoots and root systems were evaluated as previously described $(n=14)$.

Rooted cuttings of Peperomia serpens (trailing peperomia), P. serpens 'Variegata' (variegated trailing peperomia), and $P$. obtusifolia (Baby rubber plant) were potted on 29 Dec. 1993. Experimental procedures were the same as described for $C$. odorata with the following differences: plants were potted in round pots (top $=11 \mathrm{~cm}$ in diameter) filled with 0.5 liters of medium as previously described, fertilized with $12 \mathrm{~g}$ of Osmocote $18 \mathrm{~N}-$ $3.1 \mathrm{P}-10 \mathrm{~K}$, grown with an average $29 \mathrm{C}$ maximum/21C minimum, and pinched on 21 Mar. 1994. Leaf and stem dry weights were determined 15 and 19 weeks after potting for $P$. serpens and $P$. obtusifolia, respectively. Root coverage on the exterior of the rootball was rated, and data were analyzed as previously described $(n=15)$.

Table 1. Height growth rate, plant growth rate, root dry weight, shoot : root ratio, and root coverage of Swietenia mahagoni as influenced by $\mathrm{Cu}(\mathrm{OH})_{2}$ treatment of interior container surfaces.

\begin{tabular}{|c|c|c|c|c|c|}
\hline $\mathrm{Cu}(\mathrm{OH})_{2}$ & $\begin{array}{c}\text { Ht } \\
\text { growth rate } \\
\left(\mathrm{mm} \cdot \mathrm{day}^{-1}\right)\end{array}$ & $\begin{array}{c}\text { Plant } \\
\text { growth rate } \\
\left(\mathrm{g} \bullet \mathrm{day}^{-1}\right)\end{array}$ & $\begin{array}{l}\text { Root } \\
\text { dry wt } \\
(\mathrm{g})\end{array}$ & $\begin{array}{c}\text { Shoot : root } \\
\text { ratio } \\
\left(\mathrm{g} \cdot \mathrm{g}^{-1}\right)\end{array}$ & $\begin{array}{c}\text { Root } \\
\text { coverage }^{z}\end{array}$ \\
\hline+ & 4.5 & 0.21 & 0.71 & 2.7 & 1.1 \\
\hline- & 3.5 & 0.26 & 0.92 & 2.0 & 3.8 \\
\hline
\end{tabular}

${ }^{2}$ Root coverage: $1,<20 \%$ of rootball covered with white root tips, no root circling; $2, \approx 50 \%$ of rootball covered with white root tips, moderate root circling; $5,>80 \%$ of rootball covered with white root tips, extensive root circling.

${ }^{*}, * *, * * *$ Significant at $P \leq 0.05,0.01$, or 0.001 , respectively $(\mathrm{n}=15)$.

Table 2. Shoot height, shoot dry weight, and root coverage of Leea coccinea as influenced by $\mathrm{Cu}(\mathrm{OH})_{2}$ treatment of interior container surfaces.

\begin{tabular}{lcccc}
\hline \hline & $\begin{array}{c}\text { Shoot ht } \\
\text { after } \\
14 \mathrm{wks}\end{array}$ & $\begin{array}{c}\text { Shoot ht } \\
\text { after } \\
\end{array}$ & 18 wks & Shoot \\
$\mathrm{Cu}(\mathrm{OH})_{2}$ & $(\mathrm{~m})$ & $(\mathrm{m})$ & $\begin{array}{c}\text { dry wt } \\
(\mathrm{g})\end{array}$ & $\begin{array}{c}\text { Root } \\
\text { coverage }^{\text {z }}\end{array}$ \\
\hline+ & 1.2 & 1.4 & 134 & 1.2 \\
- & 1.1 & 1.2 & 108 & 3.1 \\
& $*$ & $* * *$ & $*$ & $* * *$
\end{tabular}

${ }^{2}$ Root coverage as described in Table 1.

${ }^{*},{ }^{* * *}$ Significant at $P \leq 0.05$ or 0.001 , respectively $(\mathrm{n}=14)$.
Table 3. Root coverage of seven subtropical plants as influenced by $\mathrm{Cu}(\mathrm{OH})_{2}$ treatment of interior container surfaces.

\begin{tabular}{lccr}
\hline \hline & & \multicolumn{2}{c}{ Root coverage } \\
\cline { 3 - 4 } & & $\mathrm{Cu}(\mathrm{OH})_{2}$ \\
\cline { 3 - 4 } Species & $\mathrm{n}$ & + & - \\
\hline Cedrela odorata & 14 & $1.2^{* * * *}$ & 3.2 \\
Eriobotrya japonica & 14 & $1.1^{* * * *}$ & 3.0 \\
Peperomia serpens & 15 & $1.0^{* * *}$ & 3.9 \\
P. serpens 'Variegata' & 15 & $1.0^{* * *}$ & 3.8 \\
P. obtusifolia & 15 & $1.0^{* * *}$ & 2.4 \\
Radermachera sinica & 10 & $1.0^{* * *}$ & 4.3 \\
Schefflera actinophylla & 10 & $1.1^{* * *}$ & 3.8
\end{tabular}

${ }^{2}$ Root coverage as described in Table 1.

${ }^{* * * *}$ Significant at $P \leq 0.001$.

Applying $\mathrm{Cu}(\mathrm{OH})_{2}$ had no influence on shoot heights or weights but did reduce root coverage on the exterior of the rootball for $C$. odorata, E. japonica, $P$. serpens, $P$. serpens 'Variegata', $P$. obtusifolia, $R$. sinica, and $S$. actinophylla (Table 3). Shoot heights averaged 469, 368, 455, and $592 \mathrm{~mm}$ for C.odorata, E. japonica, $R$. sinica, and S. actinophylla, respectively. Shoot dry weights averaged 7.6, 6.9,7.7,4.6, 8.1,3.2, and $90.1 \mathrm{~g}$ for C. odorata, E. japonica, P. serpens, $P$. serpens 'Variegata', $P$. obtusifolia, $R$. sinica, and S. actinophylla, respectively. Our data for $S$. actinophylla are consistent with those of Case and Arnold (1992), who reported noinfluence of $\mathrm{Cu}(\mathrm{OH})_{2}{ }^{-}$ treated containers on shoot growth of Schefflera arboricola (Hayata) Hayata. In Svenson and Johnston's (1992) study, $R$. sinica was grown in $\mathrm{Cu}(\mathrm{OH})_{2}$-treated square pots (top $=56 \mathrm{~mm}$ in diameter; $150 \mathrm{ml}$ of medium) for 3 weeks, and shoots were shorter and had less dry weight than plants grown in nontreated pots. Shoot growth responses of $R$. sinica to $\mathrm{Cu}(\mathrm{OH})_{2}$ treatment may vary according to container size.

The lack of shoot growth response to $\mathrm{Cu}(\mathrm{OH})_{2}$ treatment for six of eight species in this study contrasts with reports of increased or decreased shoot growth for some temperate species (Arnold, 1992; Arnold and Struve, 1993; Beeson and Newton, 1992; Ruter, 1994). As indicated by root coverage, control of root growth on the exterior of the rootball in $\mathrm{Cu}(\mathrm{OH})_{2}$-treated containers was excellent for S. mahagoni (Table 1); L. coccinea (Table 2); and $C$. odorata, E. japonica, and $S$. actinophylla (Table 3). Similar reductions in malformed roots in $\mathrm{Cu}(\mathrm{OH})_{2}$-treated containers have been reported for a variety of temperate species (Arnold, 1992; Arnold and Struve, 1993; Beeson and Newton, 1992; Ruter, 1994). Root growth on the surface of the rootball was eliminated completely for $P$. serpens, $P$. obtusifolia, and $R$. sinica (Table 3 ), consistent with an earlier study on $R$. sinica (Svenson and Johnston, 1992) and with various temperate species (Beeson and Newton, 1992; Case and Arnold, 1992; Ruter, 1994). Shoot height growth rate of $S$. mahagoni and shoot height and weight of $L$. coccinea increased when grown in $\mathrm{Cu}(\mathrm{OH})_{2}{ }^{-}$ treated pots. Generally, shoot and root growth responses to $\mathrm{Cu}(\mathrm{OH})_{2}$-treated containers varied among eight subtropical species. This result is consistent with the variable responses reported for temperate species. 


\section{Literature Cited}

Arnold, M.A. 1992. Timing, acclimation period, and cupric hydroxide concentration alter growth responses of the Ohio production system. J. Environ. Hort. 10(2):114-117.

Arnold, M.A. and D.K. Struve. 1993. Root distribution and mineral uptake of coarse-rooted trees grown in cupric hydroxide-treated containers. HortScience 28:988-992.

Beeson, R.C. and R. Newton. 1992. Shoot and root responses of eighteen southeastern woody landscape species grown in cupric hydroxide-treated containers. J. Environ. Hort. 10(4):214-217.

Case, G.N. and M.A. Arnold. 1992. Cupric hydroxide-treated containers decrease pot-binding of five species of vigorously rooted greenhouse crops. Proc. Southern Nurserymen's Assn. Res. Conf. 37:94-98.

Harris, R.W. 1992. Arboriculture: Integrated management of landscape trees, shrubs and vines. Prentice-Hall, Englewood Cliffs, N.J.

Ruter, J.M. 1994. Growth responses of four vigorous-rooted tree species in cupric hydroxidepainted containers. HortScience 29:1089.

SAS Institute. 1989. SAS/STAT user's guide. Ver- sion 6. SAS Institute, Cary, N.C.

Struve, D.K. 1993. Effect of copper-treated containers on transplant survival and regrowth of four tree species. J. Environ. Hort. 11(4):196-199.

Svenson, S.E. and T.K. Broschat. 1995. Growing West Indian mahogany and carpentaria palm in $\mathrm{Cu}(\mathrm{OH})_{2}$-treated containers alters root distribution and shoot growth after transplanting. J. Environ. Hort. (In press.)

Svenson, S.E. and D.L. Johnston. 1992. Faster growth of Radermachera sinica after transplanting from copper-treated liners. Proc. Southern Nurserymen's Assn. Res. Conf. 37:100-102. 